\title{
RANCANG BANGUN SENSOR LEVEL BERBASIS SENSOR TEKANAN PADA TANGKI PROSES MINYAK KELAPA
}

\author{
Akhmad Fahruzi \\ Teknik Elektro ITATS, Jl. Arief Rahman Hakim No. 100 Surabaya \\ Email: fahruziakhmad@gmail.com
}

\begin{abstract}
Many methods are used in measuring the level of a liquid, such as using ultrasonic waves, capacitance and optical fiber. However, when three methods applied to companies, it will be many obstacles in the fabrication. This is because the palm oil storage tank has a height up to $12 \mathrm{~m}$ with temperature up to $80^{\circ} \mathrm{C}$. In addition, the state of the tank always filled with oil and sealed, but there a hole for air circulation evaporation. Thus, in this study applied the method is to measure pressure fluid palm oil depend of this level. However, the method has a dependency with characteristic of the fluid (palm oil), such as density value of the oil. To find the value of density's oil, then the experiments is changing value of the temperature the oil. Designing this tool, temperature sensor PT100 type is used to measure the temperature of oil and this pressure measure is used pressure sensor MIDAS pressure transmitter. From the experimental results of the density value of palm oil, increasing the temperature's oil can decrease the density of it and vice versa. Level's measurement use Bernouli equation as the equation for the calibration when applied to the mechanics model and the oil's tank in the company which has an error less than $10 \%$ with an average error at the level below $60 \mathrm{~cm}$.
\end{abstract}

Keywords: fluid, level measurenent, pressure sensor, density of plm oil, temperatur sensor PT100.

\begin{abstract}
ABSTRAK
Banyak metode yang dipakai didalam mengukur level suatu zat cair, diantarannya adalah menggunakan metode gelombang ultrasonik, kapasitansi dan fiber optik. Akan tetapi, dari ketiga metode tersebut bila diterapkan pada perusahaan minyak kelapa, maka akan banyak menemukan kendala dalam fabrikasinya. Hal ini dikarenakan tangki proses minyak kelapa memiliki ketinggian sampai $12 \mathrm{~m}$ dengan temperatur sampai $80^{\circ} \mathrm{C}$. Selain itu juga keadaan tangki yang selalu terisi minyak dan tertutup rapat, hanya terdapat lubang untuk sirkulasi udara penguapan. Sehingga dalam penelitian ini diterapkan metode fluida yaitu dengan menerapkan hubungan tekanan minyak kelapa pada tangki proses dengan levelnya. Akan tetapi metode fluida memiliki ketergantungan dengan karakteristik fluidanya (minyak kelapa), salah satunya adalah massa jenis minyak kelapa, sedangkan massa jenis memiliki hubungan dengan temperatur. sehingga pada penelitian ini, untuk mencari nilai massa jenis minyak kelapa dilakukan dengan eksperimen dengan mengubah setiap nilai temperatur dari minyaknya. Pada perancangan alat ini, dipakai sensor temperatur jenis PT100 untuk mengukur temperatur minyaknya dan pengukuran tekanannya menggunakan sensor tekanan MIDAS Pressure transmitter. Dari hasil eksperimen nilai massa jenis minyak kelapa, bahwa temperatur minyak semakin tinggi akan menurunkan nilai massa jenis minyak kelapa dan sebaliknya. Pengukuran level pada alat yang menggunakan persamaan bernouli sebagai persamaan untuk kalibrasi sudah sesuai ketika alat diterapkan ke pemodelan mekanik yang telah dibuat dan pada tangki minyak kelapa diperusahaan dan mempunyai kesalahan tidak lebih dari 10\% dengan rata-rata kesalahan terbesar berada pada level dibawah $60 \mathrm{~cm}$.
\end{abstract}

Kata kunci: fluida, pengukuran level, sensor tekanan, massa jenis minyak kelapa, sensor temperatur PT100.

\section{PENDAHULUAN}

Penerapan hukum-hukum fluida banyak dijumpai pada dunia industri untuk mengukur suatu besaran seperti tekanan (pressure), debit (flow) dan level dari suatu zat cair atau gas [1]. Salah satu contohnya penelitian yang akan dilakukan adalah pada perusahaan yang bergerak dibidang minyak kelapa yang mengolah minyak kelapa menjadi minyak setengah jadi. Dalam studi kasusnya, perusahaan ini ingin melihat jumlah hasil produksinya (minyak kelapa) secara akurat yang tersimpan didalam tangki proses minyak yang berukuran diameter $4 \mathrm{~m}$ dan tinggi $12 \mathrm{~m}$, yaitu dengan mengetahui level minyak yang ada didalam tangki proses kemudian dihitung beratnya. 
Metode yang dipakai untuk mengukur level minyak kelapa adalah dengan menerapkan hukum fluida statis yang menggunakan hubungan antara tekanan yang diberikan oleh level minyak pada tangki proses. Penggunaan metode ini karena minyak tersebut memiliki temperatur sampai $80^{\circ} \mathrm{C}$ dan fabrikasi ke tangkinya lebih mudah. Jika pengukuran level menggunakan metode yang sebelumnya sering dipakai seperti gelombang ultrasonik atau sensor jarak [2], kapasitansi [3] dan fiber optik [4] akan menemukan beberapa kendala, seperti temperatur minyak yang tinggi dan ukuran tangki yang besar. Akan tetapi permasalahan yang muncul bila menerapkan hukum fluida adalah ketergantungan dari karakteristik minyak kelapa tersebut seperti hubungan massa jenis dengan temperatur karena dua besaran tersebut memiliki pengaruh didalam menentukan tekanan dari minyak kelapa. Sehingga pada penelitian ini, dilakukan analisa fisis seperti nilai massa jenis minyak kelapa terhadap temperatur yaitu dengan melakukan eksperiment, menerapkan hukum fluida statis dalam dunia industri untuk mengukur level minyaknya dengan kesalahan tidak lebih dari $10 \%$ pada temperatur minyak yang mencapai $80^{\circ} \mathrm{C}$.

\section{TINJAUAN PUSTAKA}

\section{Perubahan Dimensional Akibat Koefisien Muai Termal dan Temperatur}

Suatu fluida jika dipanaskan dengan temperatur tertentu, maka akan mengalami perubahan dimensi yang disebabkan oleh perubahan nilai koefisian muai fluida tersebut [2]. Persamaan untuk mendefinisikan pemuaian koefisien volum yang disebabkan temperatur dengan tekanan tetap [5], yaitu:

$$
V_{t}=V_{0}(1+\gamma \Delta T)
$$

Dimana

$$
\begin{aligned}
& \gamma: \text { Koefisien volumetrik }\left({ }^{\circ} \mathrm{C}^{-1}\right) \\
& V_{0}: \text { Volum fluida sebelum pemuaian }\left(\mathrm{m}^{3}\right) \\
& V_{t}: \text { Volum fluida setelah pemuaian }\left(\mathrm{m}^{3}\right) \\
& \Delta T: \text { Perubahan temperatur }\left({ }^{\circ} \mathrm{C}\right)
\end{aligned}
$$

Pada penelitian sebelumnya [9] telah dilakukan ekseriment untuk mencari nilai koefisien muai volumetrik pada fluida jenis metil (BMR) dan etil (BER) biodiesel dari minyak residu dan dibandingkan dengan minyak diesel. Hasil yang didapat untuk nilai koefisien muainya yaitu untuk minyak diesel $8,36 \times 10^{-4}{ }^{\circ} \mathrm{C}^{-1} \pm 0,06 \times 10^{-4}$, BER $8,35 \times 10^{-4}{ }^{\circ} \mathrm{C}^{-1} \pm 0,02 \times 10^{-4}$ dan BMR $8,37 \times 10^{-4}{ }^{\circ} \mathrm{C}^{-}$ ${ }^{1} \pm 0,01 \times 10^{-4}$.

Bila menggunakan hubungan linier regresif dari ln $\left(\mu_{0} / \mu\right)$ dengan $\left(T-T_{0}\right)$, dengan $\mu_{0}$ adalah massa jenis awal dan $T_{0}$ adalah temperatur awal sedangkan $\mu$ dan $T$ adalah massa jenis dan temperatur akhir, maka didapat grafik seperti pada Gambar 1 (Da silva, 2013).

Dari persamaan 1 jika dihubungkan dengan nilai massa jenis, maka akan menjadi seperti pada persamaan 2 dibawah ini.

$$
V_{0}=\frac{m}{\rho_{0}} \text { dan } V_{t}=\frac{m}{\rho_{t}}
$$

Sehingga,

$$
\begin{aligned}
& V_{t}=V_{O}(1+\gamma \Delta T) \\
& \frac{m}{\rho_{0}}=\frac{m}{\rho_{t}}(1+\gamma \Delta T) \\
& \rho_{t}=\frac{\rho_{0}}{1+\gamma \Delta T}
\end{aligned}
$$


dimana $\quad \rho_{0}:$ Massa jenis fluida sebelum pemuaian $\left(\mathrm{kg} / \mathrm{m}^{3}\right)$

$\rho_{\mathrm{t}}:$ Massa jenis fluida setelah pemuaian $\left(\mathrm{kg} / \mathrm{m}^{3}\right)$

$m$ : Massa fluida $(\mathrm{kg})$

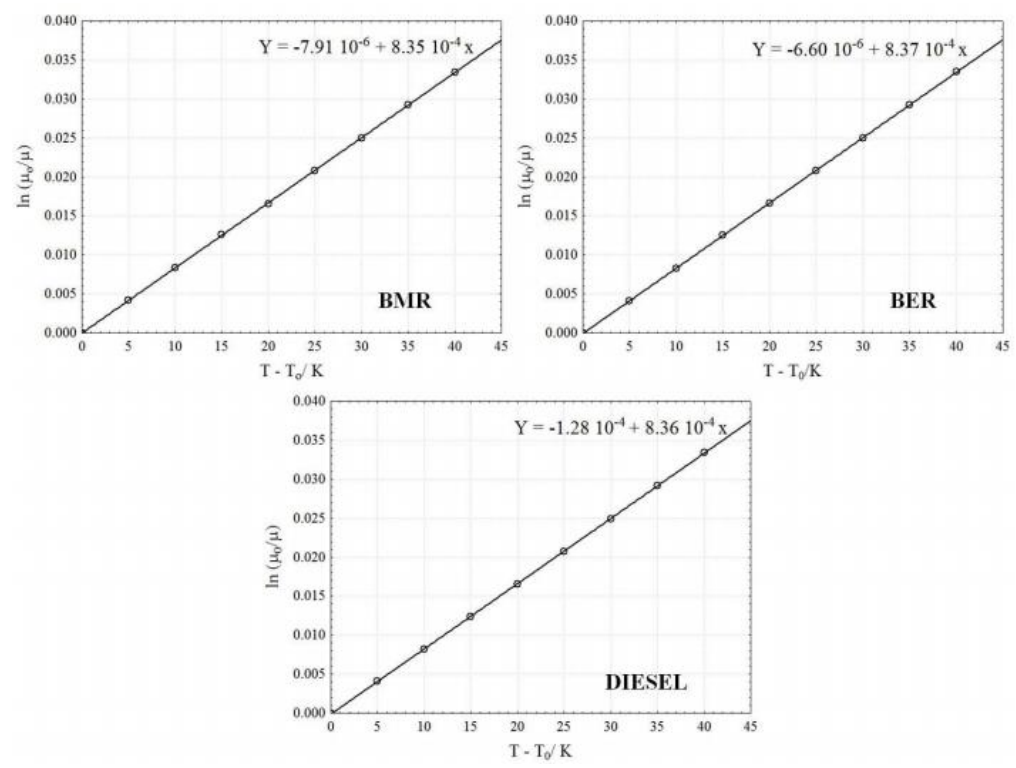

Gambar 1 Grafik untuk menentukan koefisien muai panas dari BMR, BER dan minyak diesel

Pada penelitian sebelumnya [7], telah melakukan perhitungan secara matematik untuk mencari hubungan nilai massa jenis terhadap temperatur pada minyak tumbuhan (vegetable oil) yang dipakai pada diesel dan biodiesel.

Tabel 1. Nilai massa jenis pada jenis-jenis vegetable oil [7]

\begin{tabular}{ccccccccc}
\hline $\begin{array}{c}\text { Temp } \\
\left({ }^{\circ} \mathrm{C}\right)\end{array}$ & Diesel & BD100 & Rapeseed & Sunflower & Soybean & Palm & Corn & Grapeseed \\
\hline 10 & 0,8376 & 0,8859 & 0,9210 & 0,9251 & 0,9254 & - & 0,9237 & 0,9259 \\
\hline 20 & 0,8308 & 0,8798 & 0,9145 & 0,9169 & 0,9185 & - & 0,9167 & 0,9188 \\
\hline 30 & 0,8242 & 0,8717 & 0,9080 & 0,9114 & 0,9127 & - & 0,9113 & 0,9126 \\
\hline 40 & 0,8181 & 0,8641 & 0,9027 & 0,9043 & 0,9061 & 0,8996 & 0,9046 & 0,9060 \\
\hline 50 & 0,8114 & 0,8583 & 0,8963 & 0,8994 & 0,8998 & 0,8922 & 0,8979 & 0,8998 \\
\hline 60 & 0,8043 & 0,8513 & 0,8911 & 0,8926 & 0,8941 & 0,8845 & 0,8920 & 0,8941 \\
\hline 70 & 0,7970 & 0,8433 & 0,8848 & 0,8877 & 0,8879 & 0,8789 & 0,8864 & 0,8874 \\
\hline 80 & 0,7890 & 0,8372 & 0,8777 & 0,8798 & 0,8817 & 0,8721 & 0,8801 & 0,8813 \\
\hline 90 & 0,7825 & 0,8287 & 0,8724 & 0,8743 & 0,8750 & 0,8664 & 0,8740 & 0,8754 \\
\hline 100 & 0,7759 & 0,8229 & 0,8658 & 0,8670 & 0,8689 & 0,8595 & 0,8678 & 0,8695 \\
\hline 110 & 0,7708 & 0,8150 & 0,8593 & 0,8602 & 0,8626 & 0,8535 & 0,8610 & 0,8626 \\
\hline 120 & 0,7636 & 0,8075 & 0,8537 & 0,8536 & 0,8566 & 0,8457 & 0,8555 & 0,8570 \\
\hline 130 & 0,7577 & 0,8002 & 0,8469 & 0,8472 & 0,8498 & 0,8407 & 0,8489 & 0,8505 \\
\hline 140 & 0,7516 & 0,7912 & 0,8395 & 0,8408 & 0,8430 & 0,8325 & 0,8424 & 0,8440 \\
\hline
\end{tabular}

\section{Hubungan Massa Jenis dan Tekanan}

Gambar 1 memperlihatkan hubungan massa jenis dan tekanan pada cairan didalam sebuah silinder yang dilengkapi dengan penghisap. $P_{0}$ adalah tekanan luar, maka tekanan $P$ disuatu titik $\mathrm{P}$ 
yang sebarang berjarak $h$ dibawah permukaan yang sebelah atas dari cairan diberikan dengan persamaan [6].

$$
P=P_{0}+\rho g h
$$

dimana

$g$ : gaya gravitasi $\left(9,8 \mathrm{~m} / \mathrm{s}^{2}\right)$

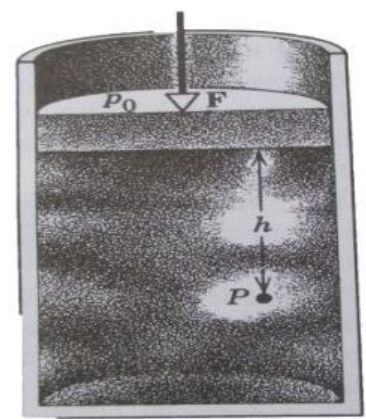

Gambar 2. Fluida dilengkapi dengan penghisap bergerak

\section{Sensor Level}

Metode pengukuran level dapat dibagi menjadi dua, yaitu pengukuran langsung dan tak langsung [10]. Besaran tekanan sering dipakai sebagai metode tidak langsung didalam mengukur level suatu zat cair. Nilai tekanan akan bertambah sebanding dengan bertambahnya zat cair tersebut. Sehingga hubungan tekanan dengan tinggi zat cair dirumuskan seperti pada persamaan 5 .

Pengukuran tekanan (sensor tekanan) yang memiliki hubungan antara tinggi dan massa jenis zat cair, maka jenis pengukuran tekanan tersebut disebut sebagai head pressure. Cara pengukuran head pressure seperti yang terlihat pada Gambar 3, sensor atau tranduser tekanan ditempatkan didasar dari zat cairnya. sehingga besarnya nilai tekanannya dapat dirumuskan sebagai [1].

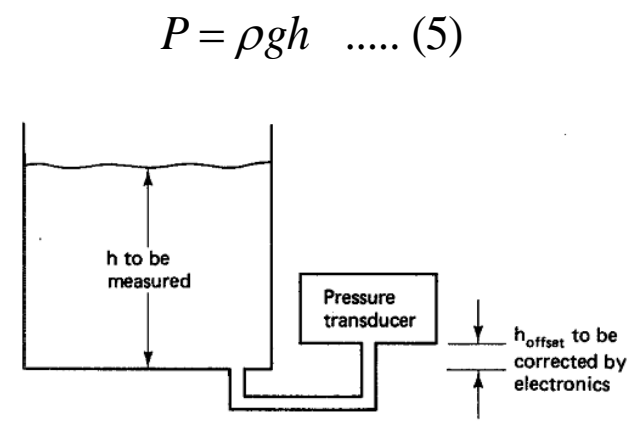

Gambar 3. Pengukuran level dengan sensor tekanan pada tangki terbuka

\section{METODE}

Sebelum alat sistem monitoring ini dipakai langsung mengukur level minyak dalam tangki di perusahaan seperti yang terlihat pada Gambar 4, dibuat terlebih dahulu pemodelan prototype dari alat ini. Pembuatan alat pemodelan ini menggunakan pipa transparan atau bening dengan ukuran seperti pada Gambar 5. Pipa transparant tersebut adalah sebagai ilustrasi dari tangki minyak aslinya yang memiliki tinggi $12 \mathrm{~m}$ dan diameter $4 \mathrm{~m}$. 


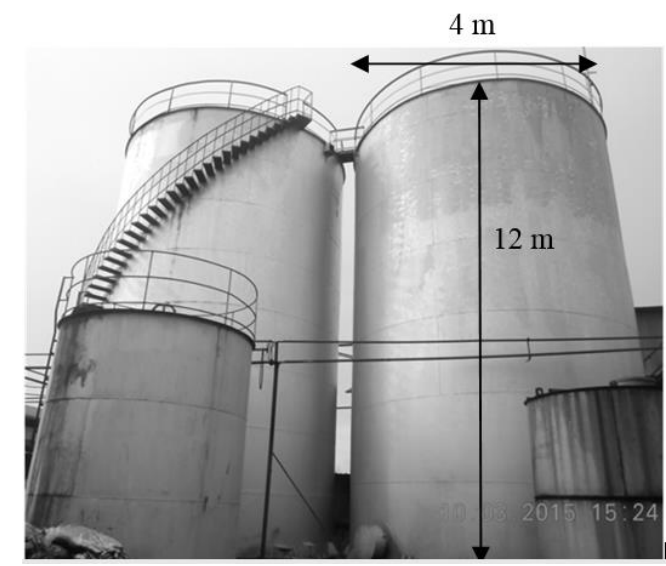

Gambar 4. Tangki proses minyak kelapa di perusahaan

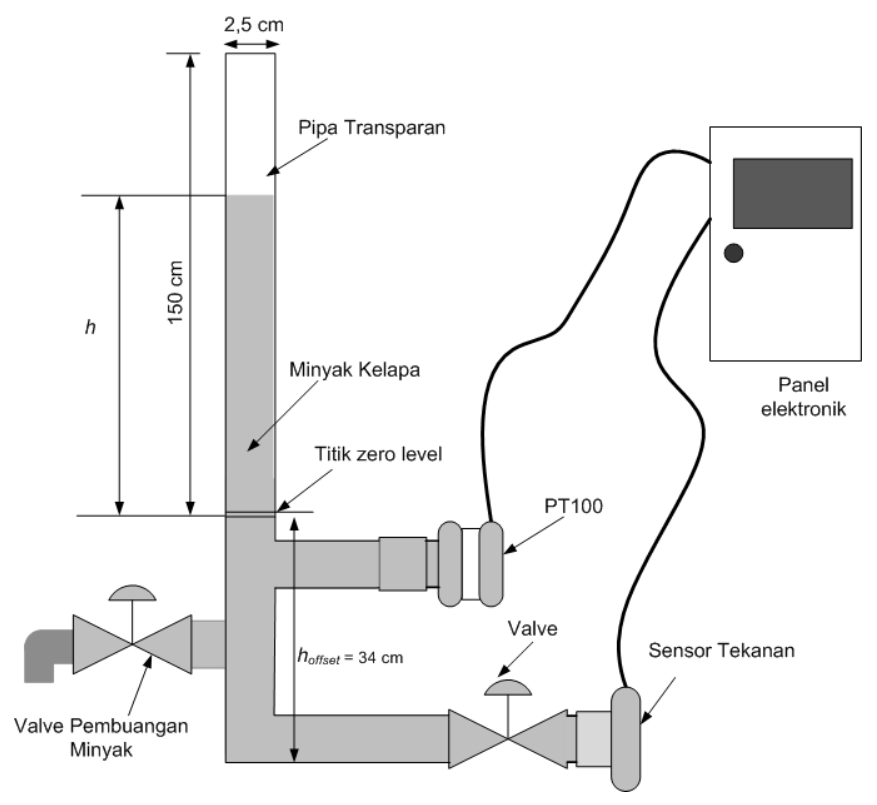

Gambar 5. Prototype alat pengukuran level minyak kelapa

Keluaran sensor temperatur PT100 dan sensor tekanan memiliki format data keluaran yang sama yaitu format datanya dari 4-20mA, sehingga pada penelitian ini pembuatan rangkaian pengkondisi sinyalnya dibuat sama. Rangkaian ini menggunakan amplifier jenis op-07 yang secara keseluruhan terbagi menjadi tiga bagian, yaitu rangkaian current to voltage converter, rangkaian penguat dan filter low pass. Besarnya Vout terhadap masukan arusnya $\left(I_{I N}\right)$ dapat dirumusakan seperti dibawah ini [1].

$$
V_{\text {OUT }}=\left(\frac{R_{F}}{R_{t}}\right) I_{I N} R_{\text {SPAN }}+V_{z}
$$

$\begin{array}{lll}\text { Dimana } & \mathrm{V}_{\text {out }} & \text { : Tegangan keluaran (volt) } \\ & \mathrm{I}_{\mathrm{IN}} & \text { : Arus masukan }(4-20 \mathrm{~mA}) \\ & \mathrm{V} & : \text { Zero voltage offset }(\text { volt }) \\ & \mathrm{R}_{\text {span }} & : \text { Resistansi span }(\mathrm{ohm}) \\ & \mathrm{R}_{\mathrm{F}} / \mathrm{R}_{\mathrm{I}} & : \text { Penguatan }\end{array}$




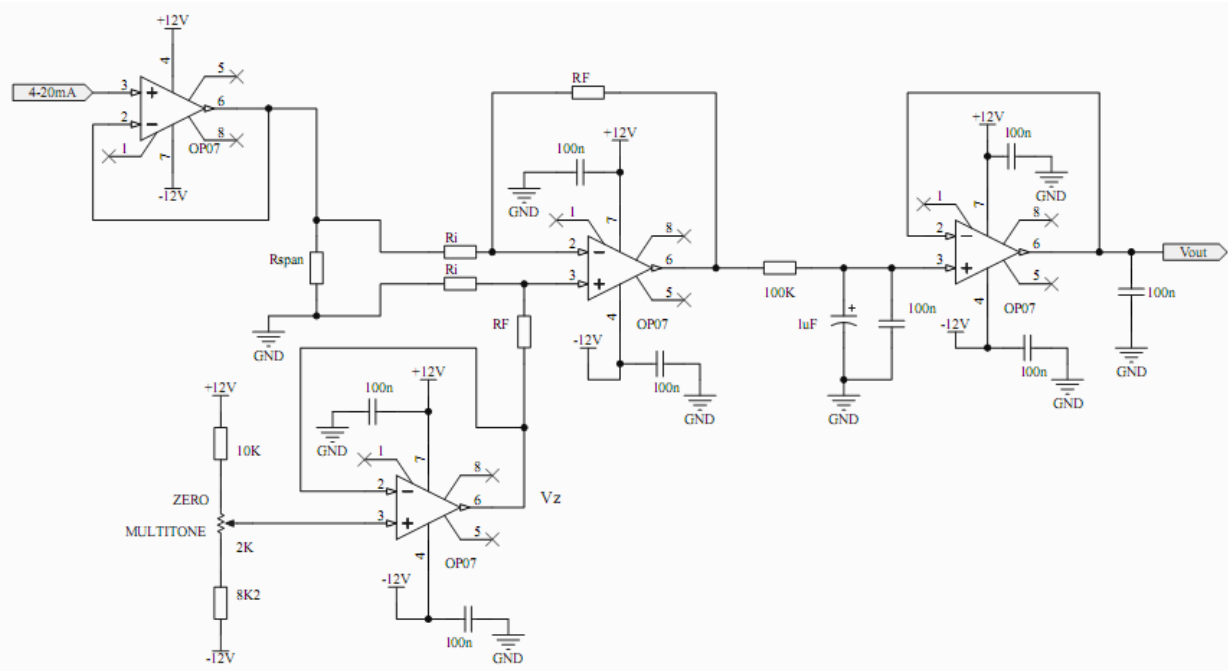

Gambar 6. Rangkaian pengkondisi sinyal sensor PT100 dan tekanan

\section{HASIL DAN PEMBAHASAN}

Bentuk prototype mekanik pada penelitian ini menggunakan pipa akrilik dengan tinggi 150 cm seperti yang terlihat pada Gambar 7.

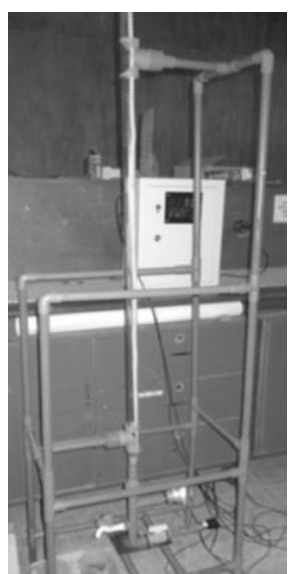

(a)

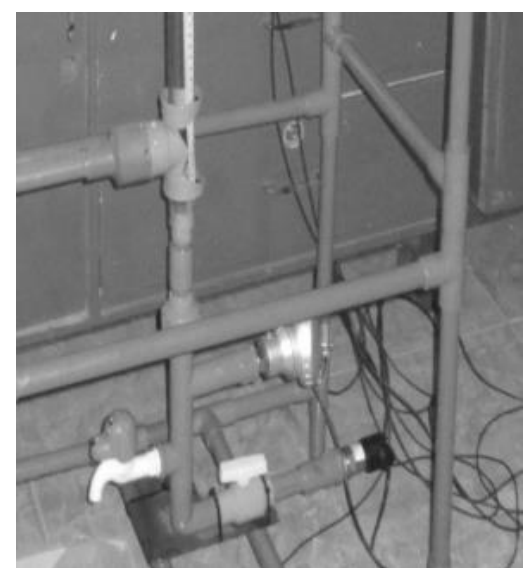

(b)

Gambar 7 (a) Prototype makanik pengukuran level

(b) Penataan sensor tekanan dan PT100

\section{Nilai Massa Jenis Minyak Kelapa terhadap Temperatur}

Proses pengukuran massa jenisnya minyak kelapa dilakukan di laboratorium zat padat FMIPA fisika ITS. Cara pengukuran yang dilakukan adalah dengan menaikkan temperatur minyak sampai $100^{\circ} \mathrm{C}$, kemudian pada temperatur $96^{\circ} \mathrm{C}$, minyak ditimbang dalam suatu wadah dengan volum $25 \mathrm{ml}$. 


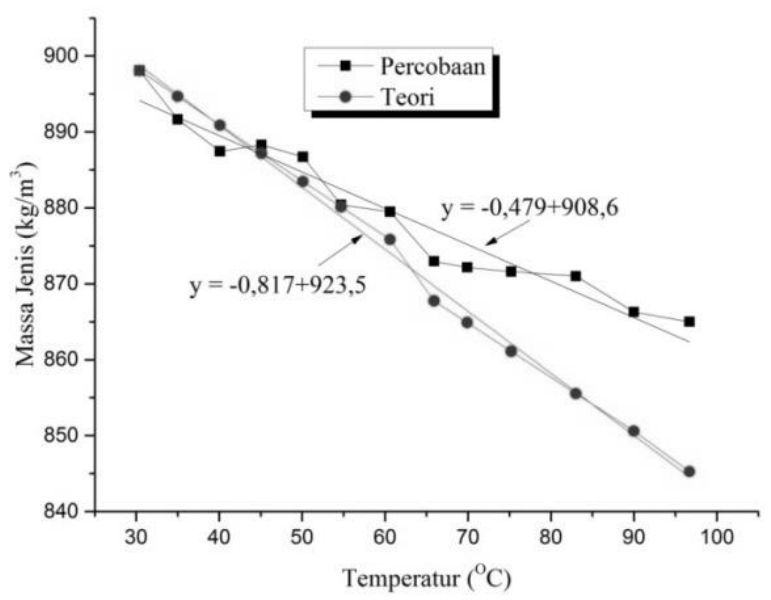

Gambar 8. Grafik hubungan massa jenis minyak kelapa terhadap temperatur.

Perbandingan nilai massa jenis minyak kelapa setengan jadi dari percobaan dengan nilai massa jenis minyak kelapa dari hasil perhitungan dari persamaan $2\left(\gamma=8,36.10^{-4} /{ }^{\circ} \mathrm{C}, \rho_{0}=898,08 \mathrm{~kg} / \mathrm{m}^{3}\right)$ dengan temperatur awal $T_{0}=30^{\circ} \mathrm{C}$ dan $\Delta T=5^{\circ} \mathrm{C}$.

\section{Pengujian Karakteristik Statik Sensor Tekanan}

Pengujian ini bertujuan untuk mengetahui karakteristik sensor tekanan yang dipakai seperti akurasi, hysteresis, linieritas dan repeatability-nya. Dalam pengujian ini, pengukuran levelnya dari $0 \mathrm{~cm}$ sampai $150 \mathrm{~cm}$ dengan step setiap $5 \mathrm{~cm}$ untuk pengukuran increasing dan decreasing.

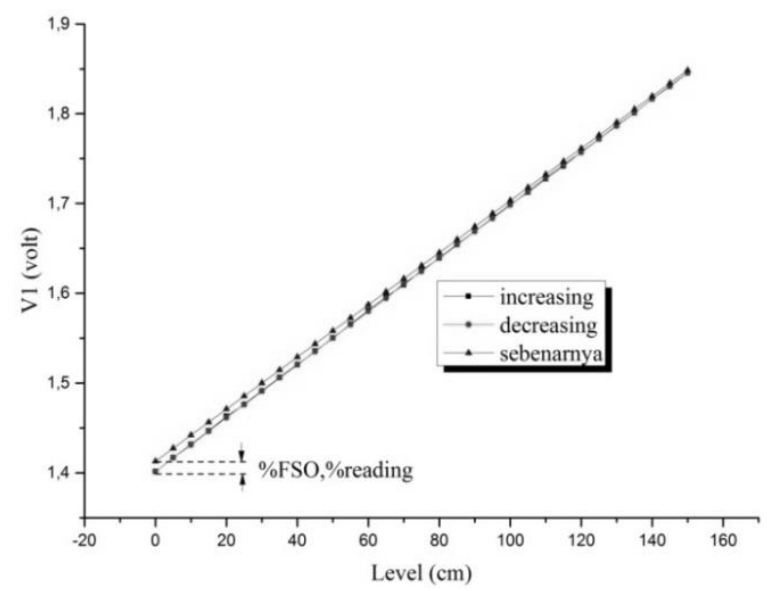

Gambar 9. Akurasi sensor tekanan

Didapatkan akurasi sensor dengan $0,62 \%$ FSO yaitu pada level $0 \mathrm{~cm}$ saat pengukuran increasing atau decreasing memiliki nilai sama dan didapat $0,81 \%$ reading terjadi pada level $0 \mathrm{~cm}$ yang memiliki nilai yang sama saat pengukuran increasing dan decreasing. Hysteresis antara pengukuran increasing dan decreasing terjadi pada level $115 \mathrm{~cm}$ yaitu $-0,108 \%$ FSO. Nilai linieritas sensor tekanan $0,152 \%$ FSO terjadi pada level $20 \mathrm{~cm}$ untuk pengukuran increasing dan $0,152 \% \mathrm{FSO}$ terjadi pada level $70 \mathrm{~cm}$ untuk pengukuran decreasing.

\section{Kalibrasi Sensor Tekanan ke Besaran Level}

Besaran level didapat dengan menggunakan persamaan 4, dengan mensubsitusi nilai massa jenis $\rho$ dengan persamaan hasil kurva fitting pada Gambar 8 yang merupakan fungsi temperatur $(T)$, sehingga persamaan kalibrasi dari tekanan $(P)$ ke level $(h)$ adalah 


$$
h=\frac{P}{(-0,479 T+908,6) 9,8}+h_{\text {offset }}
$$

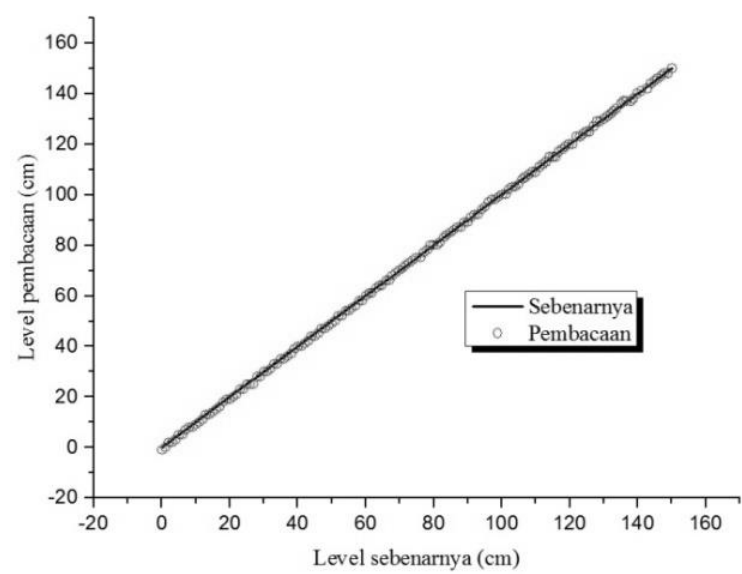

Gambar 10. Hasil pengukuran level

Persentase kesalahan semakin besar (diatas 2\%) sering terjadi pada level dibawah $60 \mathrm{~cm}$. Sedangkan untuk persentase yang diatas $10 \%$ terjadi pada level 10, 9, 6, 4 dan $3 \mathrm{~cm}$.

\section{Pengujian Level dengan Menaikkan Temperatur Minyak}

Pada pengujian ini dilakukan lima pengukuran dengan temperatur $26^{\circ} \mathrm{C}, 30-32^{\circ} \mathrm{C}, 43-50^{\circ} \mathrm{C}$, $52-61^{\circ} \mathrm{C}, 66-67^{\circ} \mathrm{C}$ dan satu pengukuran dengan nilai massa jenis tetap $\left(894,23 \mathrm{~kg} / \mathrm{m}^{3}\right)$. Perbandingan keenam pengujian seperti yang terlihat pada Gambar 11 menujukkan bahwa kesalahan pembacaan level menjadi besar jika temperatur minyak semakin tinggi dengan nilai massa jenis tetap. Kesalahan untuk massa jenis yang berubah terhadap temperatur diatas $2 \%$ saat pada level dibawah $60 \mathrm{~cm}$ kecuali pada level dibawah $20 \mathrm{~cm}$ sampai diatas $10 \%$. Sedangkan kesalahan pengukuran dengan massa jenis tetap pada semua level bernilai diatas $4 \%$. Dengan pemodelan ukuran prototype pada penelitian ini, selisih level pembacaan antara lima pengukuran dengan massa jenis bernilai tetap adalah $4-6 \mathrm{~cm}$.

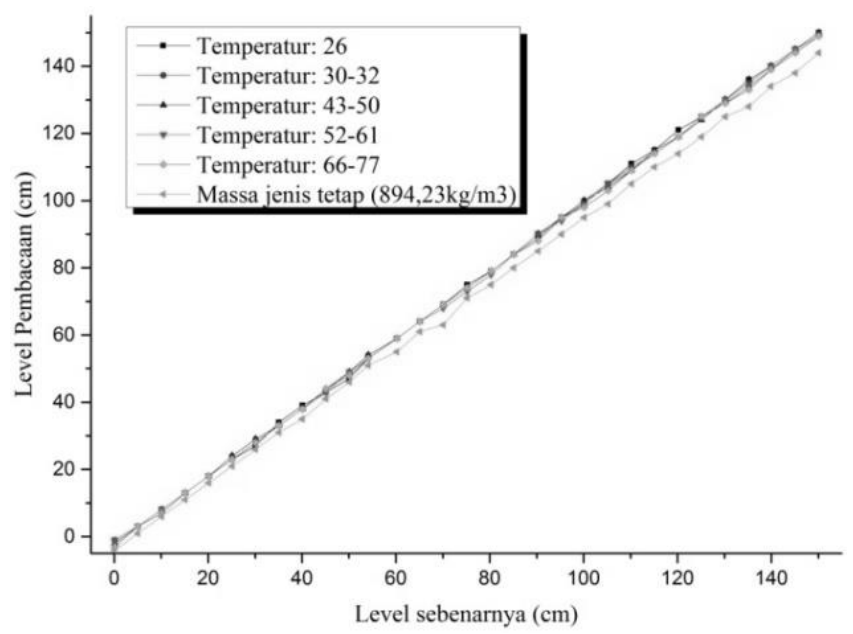

Gambar 11. Perbandingan pengukuran level saat temperatur dinaikkan dengan massa jenis yang dipengaruhi dan tidak dipengaruhi temperature 


\section{Pengukuran Level di Perusahaan}

Pengukuran level ini langsung menerapkan alat ke tangki proses minyak kelapa diperusahaan. Pada penelitian ini, lama pengambilan data dilakukan selama enam hari. Hasil pengujian pengukuran level yang didapat, level maksimal yang diukur hanya sampai $\pm 3 \mathrm{~m}$ dengan temperatur maksimal $37,8^{\circ} \mathrm{C}$. Nilai kesalahan yang paling besar yaitu $7,69 \%$ pada level terendah selama proses pengambilan data yaitu $13 \mathrm{~cm}$.

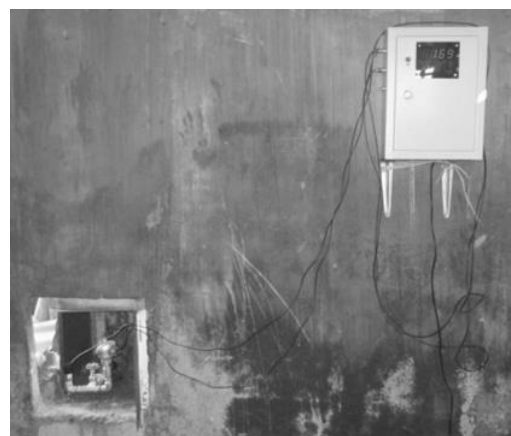

(a)

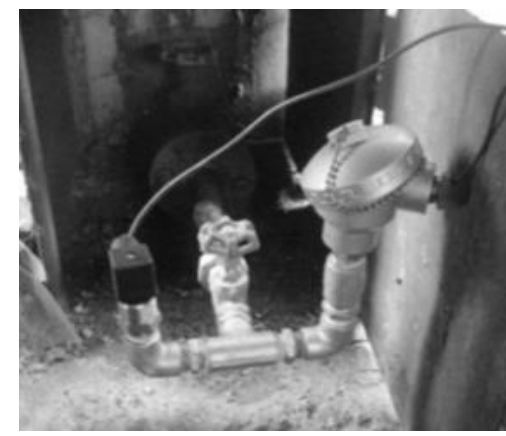

(b)

Gambar 12. (a) Peletakan sensor tekanan, PT100 dan panel elektronik

(a) Peletakan sensor tekanan, PT100 pada pipa saluran tangki minyak

\section{KESIMPULAN}

Berdasarkan data hasil pengujian, minyak kelapa memiliki hubungan linier terhadap temperatur yaitu semakin tinggi temperatur maka semakin kecil nilai massa jenisnya. Proses kalibrasi alat dari besaran tekanan ke besaran level yang menggunakan hukum fluida (persamaan bernouli) sudah sesuai ketika alat diaplikasikan ke pemodelan mekanik yang dibuat dan di tangki perusahaan.

Sensor tekanan yang digunakan memiliki karakteristik statik yang baik, Dengan pengukuran level memiliki kesalahan tidak lebih dari $10 \%$ dan memiliki kesalahan yang kecil saat level berada pada level $60 \mathrm{~cm}$ ke atas, dibandingkan dengan $60 \mathrm{~cm}$ ke bawah. Dan alat yang dibuat memiliki hasil atau karakteristik yang sama ketika diaplikasikan pada pemodelan prototype mekanik dengan tangki minyak kelapa diperusahaan.

\section{DAFTAR PUSTAKA}

[1] J.Michael Jacob (1989) "Industrial Control Electronics Applications and Design" London, Prentice-Hall International.

[2] V.E.Sakharov, S.A.Kuznetsov, B.D.Zaitsev b, I.E.Kuznetsova, S.G.Joshi (2002) "Liquid level sensor using ultrasonic Lambwaves". Vol. 41, hal 319-322.

[3] Baoquan Jina, Zeyu Zhang, Hongjuan Zhang (2015), "Structure Design and Performance Analysis of a Coaxial Cylindrical Capacitive Sensor for Liquid-Level Measurement".

[4] Weihua Zhang, Zesheng Ying, ShuoYuan (2014) "A fiber Laser Sensor forliquid level and temperature based on two taper structures and fiber Bragg grating". Vol.342 hal 243-246.

[5] Tippler (1998), "Prinsip Dasar Fisika untuk Sains dan teknik", Erlangga, Jakarta.

[6] Pantur Silaban Ph.D, Drs. Erwin Sucipto M.Sc (1985), "Fisika jilid 1 edisi ketiga", Erlangga, Jakarta, hal 562.

[7] Bernat Esteban, Jordi Roger Riba, Grau Baquero, Antoni Rius, Rita Puig (2012) "Temperatur Dependence Of Density And Viscosity Of Vegetable Oils".Vol.62, hal 169171.

[8] Sarath TM, Subha Hency Jose P, Daniel Furtado (2013). "Level Measurement Using MEMS Sensors", Vol 3, hal 118-121. 
[9] Da Silva, T.A.R, Santos, D.Q, De Lima, A.P, Neto, W.B (2013), "Volumetric Property for tankage of Biodesel from Residual Oil". Vol 5, hal 806-816.

[10] William C.Dunn (2005) "Fundamental of Industrial Instrumentation and Process Control" USA, McGraw-Hill.

[11] Jumo "Midas Pressure Transmitter type 401001/000-455-405-523-20-601-61/591".

[12] Ziehl industrie-elektronik(2014) "PT100-Temperature-Sensor type TF", TF101ZG2

[13] Richard H.Barnet, sarah Cox and Larry O'Cull (2007) "Embedded C Programming And the Atmel AVR $2^{\text {th", }}$ Kanada, Thomson Delmar Learning. 